\title{
INFLUENCE OF THE BIODIESEL FUELS WITH MULTIFUNCTIONAL ADDITIVES ON THE DIESEL ENGINE EFFICIENCY
}

Renaldas BARANAUSKAS, Department of Power and Transport Machinery Engineering, Faculty of Agricultural Engineering. Aleksandras Stulginskis University, Universitetas g. 10. Akademija. LT-53361, Kaunas raj., Lithuania, renaldasb@ gmail.com (corresponding author) Risto ILVES, Institute of Technology, Estonian Univesity of Life Sciences, Fr. R. Kreutzwaldi 56/1, Tartu 51014, Estonia, risto.ilves@emu.ee

Arne KÜÜT, Institute of Technology, Estonian Univesity of Life Sciences, Fr. R. Kreutzwaldi 56/1, Tartu 51014, Estonia, arne.kyyt@emu.ee

Jüri OLT, Institute of Technology, Estonian Univesity of Life Sciences, Fr. R .Kreutzwaldi 56/1, Tartu 51014, Estonia, jyri.olt@emu.ee

The article presents the tests of the engine Valmet 320 DS installed in the teststand "Schenck Dynas3 LI 250". For these tests biodiesel produced by JSC Rapsoila was used. The test was carried out causing the engine speed to $2600 \mathrm{rpm}$ and loading gradually to maximum. Torque $\left(\mathrm{T}_{e}\right)$, engine speed $\left(\mathrm{n}_{e}\right)$, fuel consumption $\left(\mathrm{B}_{f}\right)$, the pressure in the cylinder $\left(\mathrm{P}_{e}\right)$ and exhaust gas $\mathrm{CO}, \mathrm{CO}_{2}, \mathrm{O}_{2}, \mathrm{HC}_{1}, \mathrm{NO}_{x}$ were measured. Initially, measurements were carried out using biodiesel (RME). After that, biodiesel was added with the additive Valvoline VPS HD Diesel System Complete keeping a ratio of 100:1. In order to evaluate the effects of additives the engine was working two hours using biodiesel and additive mixture. After two hours the measurements were repeated loading the engine in the same mode. The work presents the results of tests carried out.

Keywords: additives, biodiesel, diesel engine, performance, emissions

\section{INTRODUCTION}

In the global transport sector, high energy consumption is observed in the diesel engine sector. However, the oil resources on a global scale are going low, so most of the scientists are looking for substitutes or alternative fuels. Decreasing fossil fuel stocks in the world, alternative fuels are becoming more attractive and saleable. Even though most of the renewable energy technologies are more environmental friendly than conventional energy options, their acceptance is very slow because of factors such as lack of supply, economic constraints etc.

Currently the biofuels which are the most widely used in many countries are: biodiesel for diesel engines vegetable oil methyl or ethyl esters, which have good physical and chemical properties that allow using them in diesel engines. The quality of biodiesel is regulated by the relevant standards. European Union countries have standard EN 14214. United States adopted similar to the ASTM standard for biodiesel. The European standard for biodiesel includes quality indicators and tests of biodiesel (RME) data.

The main indicator of the quality of biodiesel - the ester content. It shows the extent of the transesterification reaction and amount of fatty acid methyl esters which are formed during the reaction from the oil or fat. In accordance with EN 14214 requirements the biodiesel has to consist of not less than $96.5 \%$ of fatty acid methyl esters. The rate depends on the technologies of biofuels production. The higher ester quantity is obtained by applying multi-stage transesterification process. The indicator is determined by capillary chromatography using a flame ionisation detector. Although it is not included in the standard, but informative indicator of the nature of biodiesel is its fatty acid composition determined by capillary gas chromatography. After evaluation of the fatty acid composition, it is possible to determine which raw material was used in the production of biodiesel. Free glycerides define the purity of biodiesel (Xue et al., 2011). It depends on the methods of production and purification. Free glycerides in biodiesel must not exceed $0.02 \%$ $(\mathrm{m} / \mathrm{m})$. If it does, it shows that the manufacturing process was not sufficiently effective and glycerides were not separated and leaching well, so during the storage it can part from biodiesel and concentrate at the bottom of tanks, interact with other compounds and damage the engine injection authors argue that the use of biodiesel is necessary to change the engine injection system performance, but the use of multi-improving additives and biodiesel (RME) properties of biodiesel can be used in standard diesel engines. Hypothesis system or cause the corrosion of copper, zinc and chromium alloys corrosion (Janulis et al., 2008; Apostolakou et al., 2009). The - check whether the use of multifunctional additives improve engine performance.

Copyright (C) 2015 The Authors. Published by Aleksandras Stulginskis University. This is an open-access article distributed under the terms of the Creative Commons Attribution License (CC-BY 4.0), which permits unrestricted use, distribution, and reproduction in any medium, provided the original author and source are credited. 
Modern fuel additives are very important both for improving fuel properties, as well as to increase engine longevity and improve technical characteristics. Effective characteristics of the engine also depends on the engine design, the materials and production technology of its components. On the other hand, even the engines are being constantly improved during operation of a great number of extraneous factors such fuel, oil, coolant; various sealing elements reduce their economy. Engine parts and elements wear and rub themselves during chemical and thermal processes. Although the intervals between the vehicle services are becoming longer because of improved technologies, the engine still remains one of the key elements for service. So the lengthening of the engine durability is the main object of interest for users as well as for manufacturing or service organizations. For this reason the view that the application of additives in improving fuel properties is a way to solve a number of issues related to the motor operating characteristics improvement is becoming stronger.

In the recent year's complex (multifunctional) additives which act systemically improving lubrication, cleaning, burning, corrosion and other properties are becoming more popular. These accessories appeal to consumers as they improve some fuel properties and have multiple effects. They accelerate the combustion in the cylinder of the engine as make fuel burn more smoothly.

A few authors (Lapuerta et al., 2008; Varatharajan et al., 2011) reported that the biodiesel physical properties can be uplifted by using different additives including metal based additives, antioxidants and oxygenated additives, cold flow improver etc. into biodiesel to solve the problem of cold flow properties for their large number of usage in diesel engines (Rashedul et al., 2014). Some additives were used to improve the performance and reduce exhaust emissions from diesel engines. (Lapuerta et al., 2008)

The range of benefits accruing from fuel additives is very significant and includes (Rashedul et al., 2014):

$\checkmark \quad$ Protection of fuel tanks, pipe lines and other from massively expensive corrosion.

$\checkmark \quad$ Protection of fuel system equipment in the diesel engine from catastrophic premature wear.

$\checkmark \quad$ Reduced pumping costs and energy use in long-distance fuel pipelines.

$\checkmark \quad$ Reduced refinery processing needed to meet fuel cetane and specifications.

$\checkmark \quad$ Cold flow improvement in middle distillates, maximizing use of bio fuel.

$\checkmark \quad$ Stability improvement to prolong storage life of fuels throughout the operating theatre.

$\checkmark \quad$ Fuel saving from optimized vehicle performance and economy.

$\checkmark \quad$ Emission reduction from fuel system cleanliness and combustion optimization

Biodiesel is non-explosive, nontoxic, non-flammable and biodegradable fuel (Balat, 2006) which provides reduction of many detrimental exhaust emissions. It has no $\mathrm{SO}_{x}$ emission, particulate and soot and it can be reduced polycyclic aromatic hydrocarbons emissions. However there are some disadvantages associated with the use of biodiesel fuels (Leung et al., 2010; Knothe, 2007).

Some biodiesel fuel increases $\mathrm{NO}_{x}$ emission, which have rigorous environmental regulations and relatively poor low temperature flow properties compared to conventional diesel. Another demerit is the oxidation stability of biodiesel because of containing the double bond molecules in the free fatty acid. Fuels containing bio-components present special challenge in use, for which a range of additives provide valuable benefits. Aspect include (Rashedul et al., 2014):

$\checkmark \quad$ Reduce oxidation stability.

$\checkmark \quad$ Potential for increased injector deposit formation.

$\checkmark \quad$ Corrosion in long term storage.

$\checkmark \quad$ Adverse effect on cold flow characteristics.

$\checkmark \quad$ Increased microbial contamination.

It is considered that fuel physical properties (density, viscosity and cooking area) do not change. However, their influence on engine performance and durability requires further studies.

The quality of biodiesel can be bettered by improving the technological processes, production, careful selection and processing of raw materials. However, their properties can also be improved by use of special additives which affect each characteristic or the entire set of them. Consequently, the composition of biodiesel and the use of additives Directly Affect Such properties as viscosity, density, behaviour at low temperatures, Volatility, and the cetane number (Lapuerta et al., 2010). Popularity of complex (multifunctional) additives which act systemically improving lubrication, cleaning, burning, corrosion and other properties have been growing recently. Their influence on the properties of biodiesel and engine efficiency and durability requires further studies.

The aim of the research was to investigate the combustion power, economy and exhaust emission process of the engine, operating on RME with complex additives.

\section{OBJECTS, APPARATUS AND METHODOLOGY OF THE RESEARCH}

One of the most important methods to measure the efficiency of detergent-dispersant additives is the engine test. Research used $62 \mathrm{~kW}$ four-stroke, direct injection diesel engine VALMET 320 DS, fitted with a test stand "Schenck Dynas3 LI 250“. Rapeseed oil (RME) is used for research produced by JSC "Rapsoila".

Additives are used produced by Valvoline VPS HD Diesel system Complete. The manufacturer declares that VPS HD Diesel System Complete effectively cleans and restores the complete fuel system of the heavy-duty diesel engine, restoring the engine back to its original power and performance. The product emulsifies the condensation water present in the fuel tank and protects against rust and corrosion, while the flow improver guarantees a smooth start-up at cold temperatures.

Fuel consumption is determined by weighing the fuel AVL 7351 electronic scales. Analysing summarized 10 cycles of indicator charts, which were recorded in the respective engine operating modes, the pressure in the cylinder $(\mathrm{P} e)$ 


\section{Proceedings of the 7th International Scientific Conference Rural Development 2015}

was measured. The pressure in the cylinder of the engine 1 was measured AVL 621 module with pressure sensor GH13P / AG04. Crankshaft turning angle was measured with AVL encoder. All signals were recorded at every $1^{\circ} \mathrm{crankshaft}$ rotation angle. Primarily, tests were carried out using biodiesel (RME). The biodiesel data made in JSC „Rapsoila“ are presented in Table 1.

Table 1. The general biodiesel quality requirements made in JSC "Rapsoila" and test methods (EN 14214)

\begin{tabular}{|c|c|c|c|c|c|}
\hline Characteristic & $\begin{array}{c}\text { A unit of } \\
\text { measuremen } \\
t\end{array}$ & Min. & Max. & Test Method & Actual results \\
\hline Density at $15^{\circ} \mathrm{C}$ & $\mathrm{kg} / \mathrm{m}^{3}$ & 860 & 900 & $\begin{array}{l}\text { EN ISO } 3675, \text { EN } \\
\text { ISO } 12185\end{array}$ & 884.7 \\
\hline Cetane number & - & 51.00 & - & EN ISO 5165 & 53.4 \\
\hline Kinematic viscosity at $40^{\circ} \mathrm{C}$ & $\mathrm{mm}^{2} / \mathrm{s}$ & 3.50 & 5.00 & EN ISO 3104 & 4.789 \\
\hline Flash point & ${ }^{\circ} \mathrm{C}$ & 101 & - & ISO / CD 3679 & 178 \\
\hline $\begin{array}{l}\text { Coking balance ( } 10 \% \text { of the } \\
\text { product of distillation residue) }\end{array}$ & $\%$ wt. & - & 0.30 & EN ISO 10370 & 0.29 \\
\hline Oxidation stability at $110^{\circ} \mathrm{C}$ & $\mathrm{h}$ & 6 & - & EN 14112 & 6.4 \\
\hline $\begin{array}{l}\text { Copper plate corrosion } \\
\left(3 \mathrm{~h} \text { at } 50^{\circ} \mathrm{C}\right)\end{array}$ & $\begin{array}{l}\text { degree of } \\
\text { corrosion }\end{array}$ & \multicolumn{2}{|c|}{1 class } & EN ISO 2160 & 1 \\
\hline Esters & $\%$ wt. & 96.50 & - & EN 14103 & 96.6 \\
\hline Water & $\mathrm{mg} / \mathrm{kg}$ & - & 500 & EN ISO 12937 & 250 \\
\hline Sulfated ash & $\%$ wt. & - & 0.02 & ISO 3987 & 0.005 \\
\hline Siera & $\mathrm{mg} / \mathrm{kg}$ & - & 10 & - & 3,9 \\
\hline Acid value & $\mathrm{mg} \mathrm{KOH} / \mathrm{g}$ & - & 0.50 & EN 14104 & 0.21 \\
\hline Iodine value & - & - & 120 & EN 14111 & 111.1 \\
\hline Monoglycerides value & $\%$ wt. & - & 0.80 & EN 14105 & 0.70 \\
\hline $\begin{array}{l}\text { Acid of linolenic methyl ester } \\
\text { content value }\end{array}$ & $\%$ wt. & - & 12.00 & EN 14103 & 7.9 \\
\hline Methanol & $\%$ wt. & - & 0.20 & EN 14110 & 0.01 \\
\hline $\begin{array}{l}\text { Glycerides: } \\
\text { monoglycerides } \\
\text { diglycerides } \\
\text { triglycerides } \\
\text { free glycerides } \\
\text { generic glycerides }\end{array}$ & $\begin{array}{l}\% \text { wt. } \\
\% \text { wt. } \\
\% \text { wt. } \\
\% \text { wt. } \\
\% \text { wt. }\end{array}$ & $\begin{array}{l}- \\
- \\
- \\
- \\
-\end{array}$ & $\begin{array}{c}0.80 \\
0.20 \\
0.20 \\
0.02 \\
0.25\end{array}$ & EN 14105 & $\begin{array}{c}70 \\
19 \\
19 \\
0,005 \\
24\end{array}$ \\
\hline $\begin{array}{l}\text { Group } 1 \text { of metals }(\mathrm{Na}+\mathrm{K}) \\
\text { value }\end{array}$ & $\mathrm{mg} / \mathrm{kg}$ & - & 5 & EN 14108, EN 14109 & 2.3 \\
\hline $\begin{array}{l}\text { Group } 2 \text { of metals }(\mathrm{Ca}+\mathrm{Mg}) \\
\text { value }\end{array}$ & $\mathrm{mg} / \mathrm{kg}$ & - & 5 & EN 14538 & 4.7 \\
\hline Phosphorous value & $\mathrm{mg} / \mathrm{kg}$ & - & 10 & EN 14107 & 1.9 \\
\hline Filter plugging point & ${ }^{\circ} \mathrm{C}$ & \multicolumn{2}{|c|}{$<-20$} & EN 116 & -20 \\
\hline
\end{tabular}

\section{RESULTS AND DISCUSSION}

The engine was reved up to 2600 and was gradually loaded using the test stand "Schenck Dynas3 LI 250“ and measurement took place. Then additives were poured into biodiesel containing a ratio of 100:1. In order to evaluate the effects of additives, the engine was working two hours using biodiesel and additive mixture.

Carbon monoxide $(\mathrm{CO})$ and carbon dioxide $\left(\mathrm{CO}_{2}\right)$, not completely burned hydrocarbons (HC), nitrogen oxides $\mathrm{NO}_{x}$ emissions in the exhaust manifold were measured with the gas analyser Bosch BEA 350th.

After two hours of engine operation in various modes similar measurements were performed. The dependent of engine load on speed and fuel consumption is presented in Figure 1.

In comparison engine fuel consumption did not change brightly (significantly). At speeds 1800-2400 rpm using additives fuel consumption was on average $0.25 \mathrm{~kg} / \mathrm{h}$ lower, but the maximum torque zone at 2400-2450 rpm an average of $0.33 \mathrm{~kg} / \mathrm{h}$ higher. 


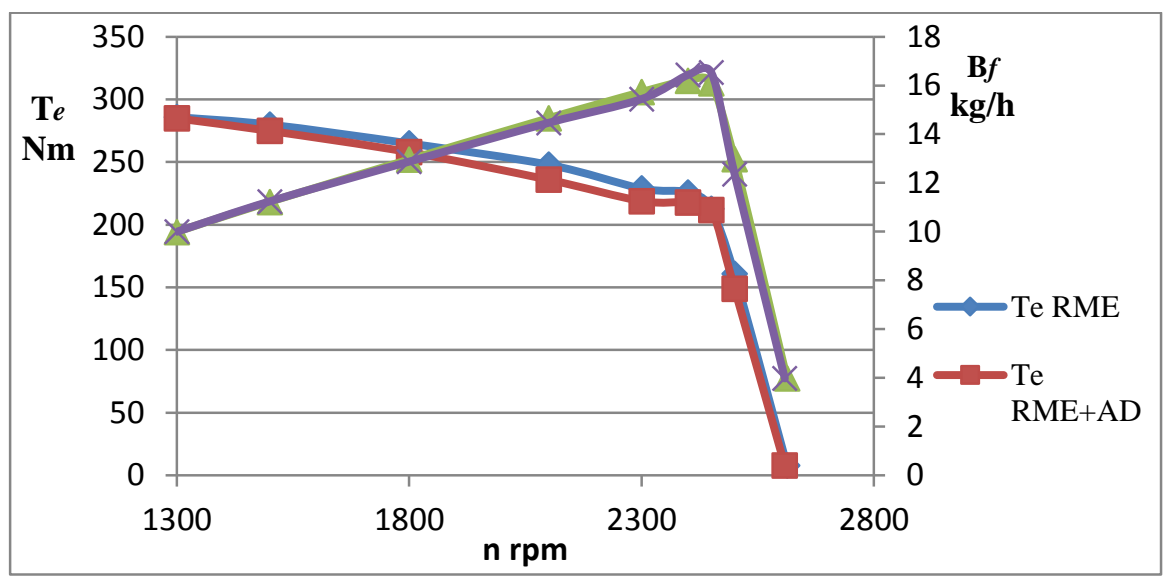

Figure 1. The dependence of engine torques $(\mathrm{T} e)$ and fuel consumption $(\mathrm{B} f)$ under loud

The load chart shows that the torque fell by an average of $10 \mathrm{Nm}$ when it is used in medium and high load area.

The pressure changes in the cylinder presented in Figure 2 . The pressure in the cylinder was measured at every $1^{\circ}$ crankshaft rotation angle at the same engine load conditions. The pressure measurement results in the cylinder received to all modes of load pressure by using additives were lower.

a)

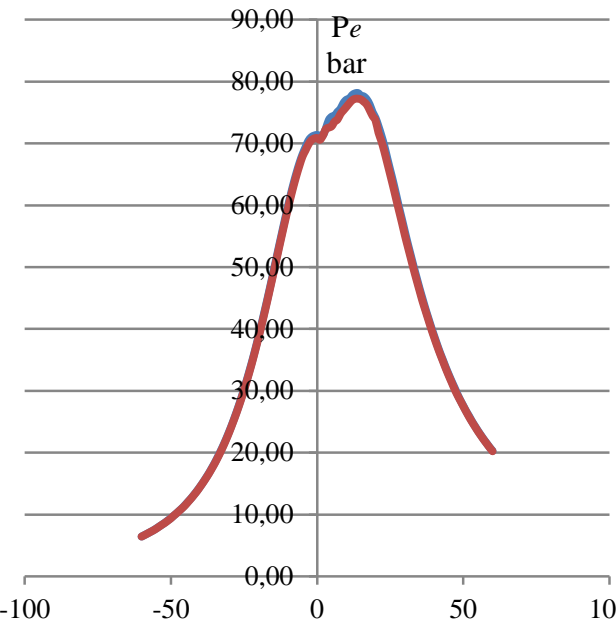

b)
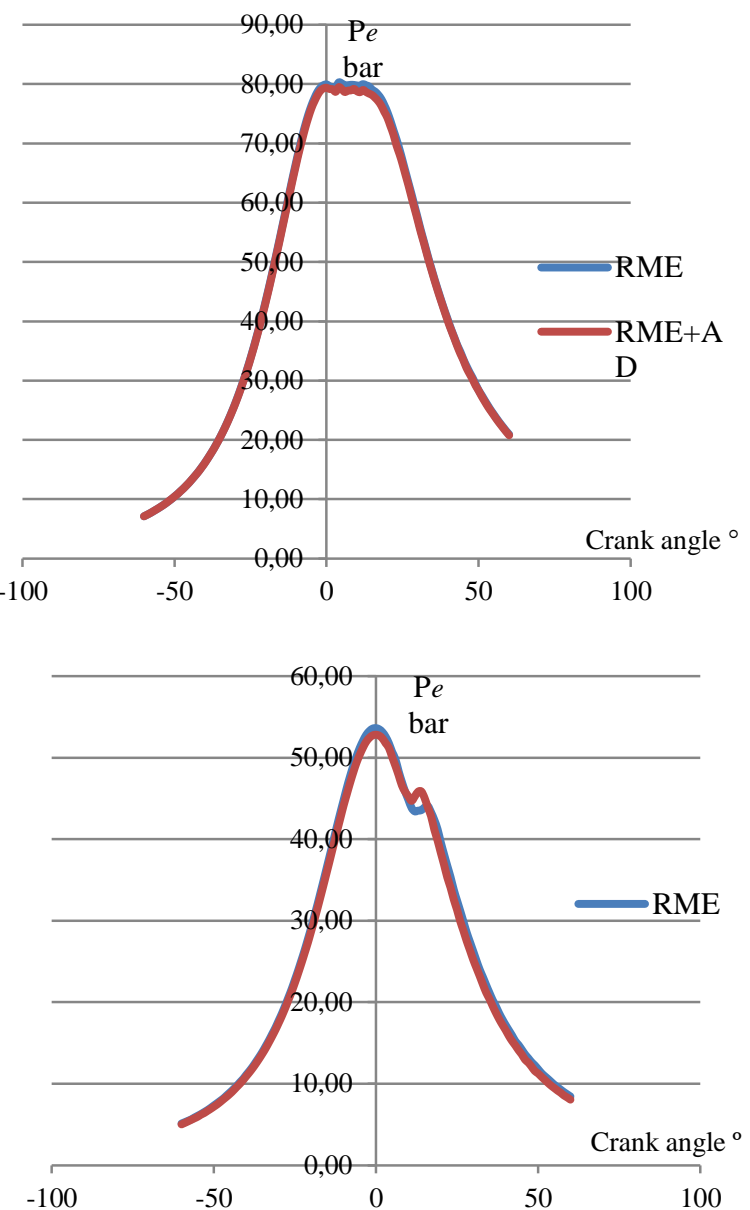

d)

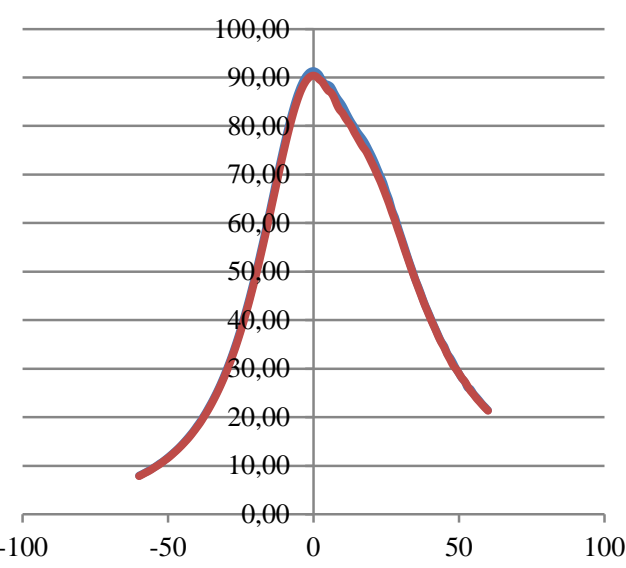

In particular, it is seen from the results obtained by measuring $2500 \mathrm{rpm}$. At these revs the speed torque using additives was an average of $12 \mathrm{Nm}$ less, and a maximum pressure difference was $\sim 8.5$ bars.

The change of exhaust gas composition under load of the engine is shown in figures 3 and 4. 

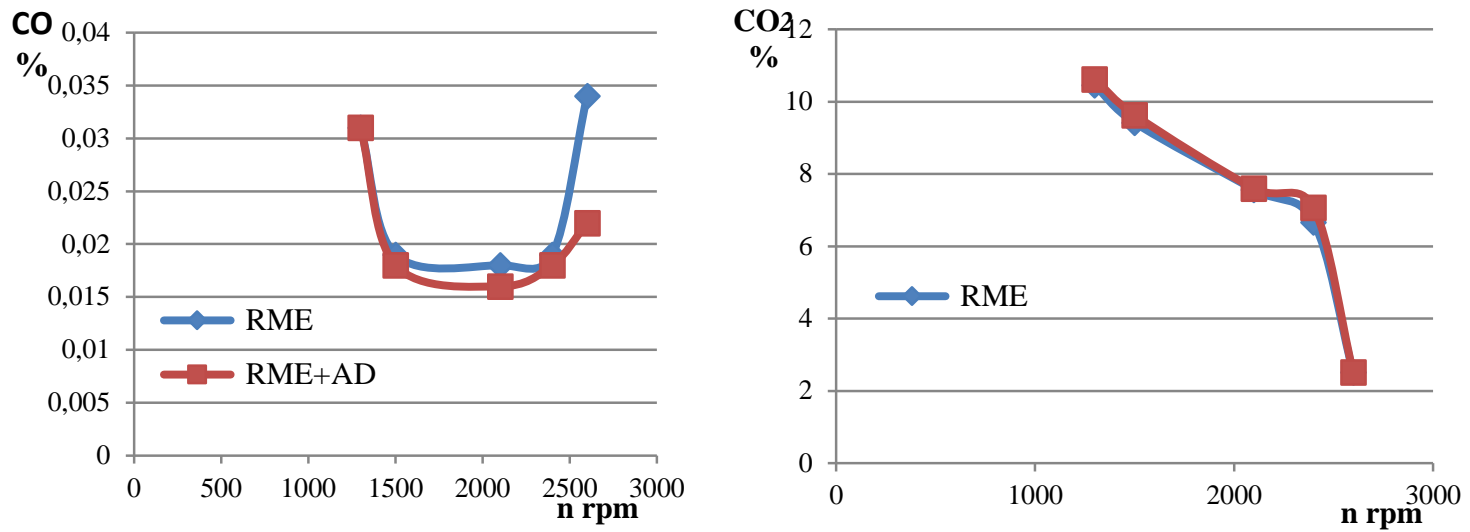

Figure 3. The content of $\mathrm{CO}$ and $\mathrm{CO}_{2}$ in the exhaust gases

Analysis of results shows that the $\mathrm{CO}$ content in the exhaust gases is reduced by using additives. Most marked decrease seen at low load average and higher speed zone. $\mathrm{CO}_{2}$ emissions slightly increased, indicating more efficient fuel combustion. More efficient fuel combustion is confirmed by the $\mathrm{HC}$ and $\mathrm{NO}_{x}$ content of exhaust gas reduction (Fig. 3 and Fig. 4).
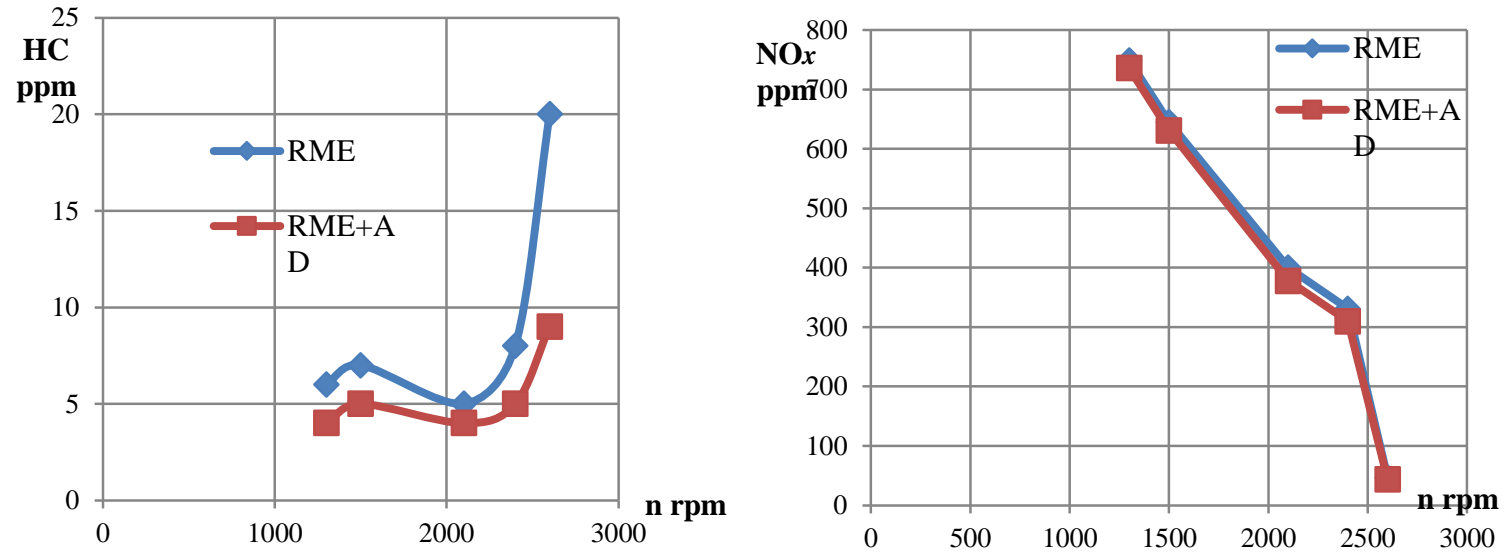

Figure 4. The content of $\mathrm{HC}$ and $\mathrm{NO}_{x}$ in the exhaust gases

\section{CONCLUSIONS}

- The engine torque was an average of $10 \mathrm{Nm}$ less when the biodiesel was added the complex additives and the engine was gradually loaded if compared to torque when pure biodiesel was used.

- The consumption of biodiesel with additives at little load to the 2400 to $2500 \mathrm{rpm}$ increased in average $0.33 \mathrm{~kg} / \mathrm{h}$, and at the 1800 to $2400 \mathrm{rpm}$ using additives fuel consumption was in average $0.25 \mathrm{~kg} / \mathrm{h}$ lower.

- The pressure in the cylinder drops when additives are used in biodiesel and this results lighter performance of the engine, but the engine torque becomes less.

- The usage of additives for the biodiesel is environmental friendly because the analysis of gasses showed the decrease of $\mathrm{CO}, \mathrm{NO}_{x}$ and $\mathrm{HC}$.

\section{REREFERENCES}

1. Apostolakou, A. A., Kookos, I. K., Marazioti, C., Angelopoulos, K. C. 2009. Techno-economic analysis of a biodiesel production process from vegetable oils. Fuel Processing Technology, Vol. 90, Iss. 7-8, pp. $1023-1031$. http://dx.doi.org/10.1016/j.fuproc.2009.04.017

2. Balat, M. 2006. Fuel characteristics and the use of biodiesel as a transportation fuel. Energy Sources Part A, 64 p.

3. Janulis, P. P., Makarevičienė, V. 2008. Technologies of producing biodiesels and oils. Engineering of biomass, Vol. 2, pp. 6-116. (In Lithuanian).

4. Knothe, G. 2007. Some aspects of biodiesel oxidative stability. Fuel Process Technoogyl, Vol. 88, Iss. 7,pp. 669-677. http://dx.doi.org/10.1016/j.fuproc.2007.01.005

5. Lapuerta, M., Herreros, J. M., Lyons, L., Garcia-Contreras, R., Briceno, 2008.Y. Effect of the alcohol type used in the production of waste cooking oil biodiesel on diesel performance and emissions. Fuel, Vol. 87, Iss.15-16, pp. 3161-3169. http://dx.doi.org/10.1016/j.fuel.2008.05.013

6. Lapuerta, M. N., Garcia-Contreras, R., Campos-Fernandez, J., Dorado, MP. 2010. Stability lubricity viscosity and cold-flow properties of alcohol - diesel blends. Energy Fuels, Vol. 24, Iss. 8, pp.4497-4502. http://dx.doi.org/10.1021/ef100498u

7. Leung, DY., Wu, X., Leung, M. A. 2010. Review on biodiesel production using catalyzed transesterification. Applied Energy, Vol. 
87, pp. 1083-10895. http://dx.doi.org/10.1016/j.apenergy.2009.10.006

8. Rashedul, H. K., Masjuki, H. H., Kalam, M. A., Ashraful, A. M., Ashrafur Rahman, S. M., Shahir, S. A. 2014. The effect of additives on properties, performance and emission of biodiesel fuelled compression ignition engine. Energy Conversion and Management, Vol. 88, pp. 348-364. http://dx.doi.org/10.1016/j.enconman.2014.08.034

9. Xue, J., Grift, T., Hansen, A. 2011. Effect of biodiesel on engine performances and emissions. Renewable and Sustainable Energy Reviews, Vol. 15, pp. 1098-1116. http://dx.doi.org/10.1016/j.rser.2010.11.016

10. Varatharajan, K., Cheralathan, M., Velraj, R. 2011. Mitigation of NOx emissions from a jatropha biodiesel fuelled DI diesel engine using antioxidant additives. Fuel, Vol. 90, pp. 2721-2725 p. 